\title{
Cosmic canticle
}

\section{Piero Boitani}

Received: 4 October 2019 / Accepted: 4 November 2019 / Published online: 19 November 2019

(c) Accademia Nazionale dei Lincei 2019

"Matter", the poet sings, "has no substance, only rhythm./ The wild dance of particles to the sound of quantum music. / Gravitational waves have no real substance; they are / simply undulations of nothingness. / Particle and wave. / Particles undulate like waves in the sea / and simultaneously are the grains of sand in the sea". ${ }^{1}$ This writer, we think, has grasped the essence of quantum theory and translated it into pure poetic images. The world of metaphor takes over the realm of mathematics, it creates poetry out of equations, out of science, of physics and astrophysics.

This operation shocks us, because we are no longer used to the mingling of images and formulas. Once upon a time, when the first thinkers of the West began to ask themselves basic questions about the world, philosophy, science, and poetry belonged to the same realm, that which stemmed from wonder, the stupor the human being feels when confronted with natural phenomena or myth. ${ }^{2}$ Homer maintained that the Ocean was the beginning of all things, and had the shield of Achilles decorated with a representation of the universe. ${ }^{3}$ Parmenides, the man who first introduced the distinction between being and non being, and who can be considered in many ways the founder of Western thought, wrote On Nature as a poem in verse, and at its very opening had himself addressed by the following words:

You will know the aethereal nature, and in the aether all

The signs [the constellations], and of the pure torch of the brilliant sun

The blinding works, and from where they are born,

And you will learn the recurrent works of the round-

eyed moon

This paper is the transcription of the speech given by the author at the Conference on GammaRay Astrophysics with the AGILE Satellite held at Accademia Nazionale dei Lincei and Agenzia Spaziale Italiana, Rome on December 11-13, 2017.

Piero Boitani

piero.boitani@uniroma1.it

Sapienza Università di Roma, Accademia Nazionale dei Lincei, Rome, Italy
And its nature, and you will also know from where the sky, which is on both sides,

Was born and how Necessity led and enchained it

To maintain the limits of the heavenly bodies. ${ }^{4}$

Heraclitus and Empedocles also dealt with the stars: the former claiming that they feed on the exhalation coming from the earth and, like Parmenides, that they are condensations of fire; the latter celebrating the sun and the aether. Lucretius, one of the greatest writers of Rome, wrote a magnificent poem on Nature where he provided an account of being and nothingness, matter and space, the atoms and their movement, the infinity of the universe both as regards time and space, the regularity of reproduction, the nature of mind and spirit as material bodily entities, and their mortality. He also offered an atomic and materialist explanation of phenomena preoccupying human reflection, such as vision and the senses, sex and reproduction, natural forces and agriculture, the heavens, and disease. The concluding sixth book contains an explanation of some of the most striking natural phenomena, especially thunder, lightning, hail, rain, snow, ice, cold, heat, wind, earthquakes, volcanoes, springs and localities noxious to animal life, which leads to a discourse upon diseases. This in its turn introduces an appalling description of the great pestilence which devastated Athens during the Peloponnesian War, and thus the book closes.

\footnotetext{
${ }^{1}$ It will soon become clear that this quotation comes from the same poem that forms the subject of the present essay.

2 This is Aristotle's view in the Metaphysics, A2, 982b 11-17. On poetry and science, see Vincenzo Schettino, La decima musa. Poesia e scienza, Florence, Florence University Press, 2016; and Piero Boitani, Il grande racconto delle stelle, Bologna, Il Mulino, 2012: English edition in two volumes, Looking Upwards. Stars in Ancient and Medieval Cultures and The Engine of the World. Stars in Modern Cultures, New York, Nova, 2017-2018.

3 Iliad XIV, 201 and 246; XVIII, 478-607.

${ }^{4}$ Parmenides D12, in Early Greek Philosophy, IV, ed. and trans. A. Laks and G.W. Most, Cambridge MA and London, Harvard University Press, 2016, pp. 54-57.
} 
Scientific and philosophical poetry was composed after antiquity. One could quote excellent examples from the School of Chartres in the twelfth century, Dante's supreme lines in the Comedy, the writers of sixteenth- and seventeenth-century France, all the way to Erasmus Darwin, who in the eighteenth century composed, again in verse, The Botanic Garden and The Temple of Nature, where he speculated on evolution, the Big Bang and the Big Crunch:

Roll on, ye Stars! exult in youthful prime,

Mark with bright curves the printless steps of Time;

Near and more near your beamy cars approach,

And lessening orbs on lessening orbs encroach; -

Flowers of the sky! ye too to age must yield,

Frail as your silken sisters of the field.

Star after star from Heaven's high arch shall rush,

Suns sink on suns, and systems, systems crush,

Headlong, extinct, to one dark centre fall,

And death and night and chaos mingle all:

- Till o'er the wreck, emerging from the storm,

Immortal Nature lifts her changeful form,

Mounts from her funeral pyre on wings of flame,

And soars and shines, another and the same $!^{5}$

It is only with the nineteenth century that poetry and science became formally divided, and we cannot now imagine a physicist writing in verse or invoking Urania, the Muse of astronomy. In the greatest of nineteenth- and twentiethcentury poems and novels, to be sure, there always is a scientific view of the universe. As notable examples I would quote Leopardi, Wordsworth, Thomas Mann, Joyce, Raymond Queneau. But in later years the poetic enthusiasm for science seems to have moved to Latin America. Haroldo de Campos, one of the greatest Brazilian poets, published in 2000 his A Maquina do Mundo Repensada, a beautiful existential-scientific poem about the structure and life of the universe. ${ }^{6}$ A few years earlier, in 1989, Ernesto Cardenal had published his Cántico cósmico, which was followed by El telescopio en la noche oscura in 1993, and Versos del Pluriverso in 2005. A Trappist monk, priest, liberation theologian, revolutionary, and minister in the government of his native country, Nicaragua, Cardenal, now 92 years old, has thus centred his poetry around the astrophysics of the late twentieth and early twenty-first centuries.

\footnotetext{
${ }^{5}$ Erasmus Darwin, The Botanic Garden, I, Canto IV, X. 1, Charleston, SC, Bibliobazaar, 2008, p. 174.

${ }^{6}$ Haroldo de Campos, A máquina do mundo repensada, São Paulo, Atelié, 2000

${ }^{7}$ Ernesto Cardenal, Cantico cósmico (1989), Madrid, Trotta, 1992: the English translation I use here, Cosmic Canticle, is by John Lyons, Willimantic CT, Curbstone Press, 1993. The page numbers refer to this edition.
}

Cántico cósmico is a magnificent work which critics trace back to Lucretius, Dante, and Ezra Pound, and in the literature of Latin America to Rubén Darío and Pablo Neruda. ${ }^{7}$ In 43 cantos it tells the story unfolding from Big Bang through to Omega, threaded throughout with visions of the cosmos told from different viewpoints: the "music of the spheres", for example, and the "dance of the stars" in cantos 20 and 30, but equally the "Birth of Venus" (12), the "tree of life" (13), the "Cántico cuántico" (29), and the "Canticle of Canticles" (41). Classical mythology and biblical icons are superimposed on the imaginary of the pre-Colombians of America, those of Islam, India, and China. Matters of the Earth are grafted onto those of the universe, introducing themes of conquest, oppression, and liberation, often recounted from the perspective of personal experience.

The strong, austere simplicity of the Canticle emerges from the very first lines in the poem's organization and voice: a direct, lightly reiterative way of speaking out to the reader in the rhythms of both prose and poetry which is immediately enchanting (1):

In the beginning there was nothing neither space nor time.

The entire universe concentrated in the space of the nucleus of an atom, and before that even less, much less than a proton, and even less still, an infinitely dense mathematical point.

The Great Explosion.

And that was Big Bang.

The universe subjected to relations of uncertainty, its radius of curvature undefined,

its geometry imprecise

with the uncertainty principle of Quantum Mechanics, spherical geometry overall but not in its detail,

like any common or garden potato undecidedly round... ${ }^{8}$

The Canticle returns obsessively to the Beginning and the Big Bang, as if in a galactic spiral, down to the final lines which conclude by returning to the beginning: "Cuando no había nada. / En el principio...". Cardenal's is not a world without God, but a world where action is through the Word: "In the beginning", the second canto recites, "before spacetime, ... was the Word. / There was no light / light was within the darkness / and he brought the light out of the darkness / drew the two apart / and that was Big Bang / or the first Revolution". Then again, going deeper, the poet joins Bible, the Greek language, and poetry (2): "Creation is a poem". "Poem", Cardenal observes, means "creation" in

\footnotetext{
8 All references in the text are to the Canto.
} 
Greek, and is St. Paul's word for divine Creation: "poiema", "like a poem by Homer". "Each thing is a like a 'like' ... like a 'like' in a Huidobro poem". Things were not created through calculation but through poetry, by the Creator who is Poietés. "The entire sense is copulation" (in the double sense, sexual and grammatical). "And each thing is word, / word of love". The Poietés creates "with finite words an infinite meaning ... The cosmos sings" (2).

"It's a constant in nature, / beauty", the fifth canto states, "Whence poetry: song and delight in all that exists... The earth could have been just as / functional, practical, / without beauty. Why then?", Cardenal asks God, "Everything is sumptuous. Did you really need to give / such luxurious jewels / to such ephemeral fish / leaping this twilight on the floor of the boat? / Love me, and if I am nothing, / I will be nothing with your beauty refracted in it". Cardenal is enraptured by God, whom he frequently addresses directly, like the mystics, and in love with poetry-from Homer to Sappho, and from Dante to Goethe. Poetry is everywhere in his poem: in the stars he evokes and compares to fireflies; in the night he throws himself into; in the leaves which, as in the Iliad, represent man; and in the hand which, in the Aurignac cave, first marked the appearance of art: "the first thing painted was the painting hand" (14). Canto 5 celebrates the stars, the Milky Way, Alpha of Orion, Alpha of the Lyre, the millions of suns in our galaxy. It exalts Galileo. It employs St Augustine, the Avatasamkata Sutra, the second law of thermodynamics, the old clock of La Merced, the nights of Solentiname in Nicaragua. Astrophysics becomes poetry.

Poetry is in the birth of Venus, the rewriting and reworking of Greek myth through which Cardenal's Muse enables him to create his song of life: "In the beginning God said: Let there be radiation", but "Who'd have said that out of such confusion / there would one day emerge such a beautiful and fragile filigree, / life. / Fresh from the sea like Venus / life. / The sea was born from the wedding of hydrogen and oxygen / and life was born from the sea / In the salt transparency / molecules transforming into protoplasm. / Venus dripping fresh from the sea" (12).

Any attempt to defeat life by the entropy Cardenal recognizes in the universe - the death pronounced inexorably on our world and each of us by the second law of thermodynamics-is foiled in the poem, since this entropy forms a "tree" of perennial evolution and metamorphosis which ensures that everything is conserved in other forms: like the leaves that die yearly to allow others to be born the following year, or like the empty sepulcher in the gospel which indicates that Christ's body is no longer there, and that (31) "death no longer has any sense".

The theology of the Cántico, moving from St. Paul and Thomas Aquinas to Teilhard de Chardin and the mystics in a constant attempt to turn into matter what tradition has attributed to the spirit is also, as in Dante's Paradiso, poetry.'In the beginning", the poet writes in canto 41 (The Canticle of Canticles), "the cosmos was shapeless and empty / and the Spirit of God brooded over the radiation, / The universe was still radiation and not matter. / And time began. / Matter and antimatter / burst forth from pure radiation, / from pure energy".

Poetry is within events and personal memories: a visit to Weimar, the community of Solentiname founded by Cardenal, memories of the Unites States, the death of a disciple and friend, Laureanno (35), the evocation of women he had loved before entering La Trappe, and the sacrifice celibacy imposes. Love governs all, and that of the atoms is called magnetism. 'But the greatest force known to nature / a hundred times greater than the electromagnetic one / binds the nucleus. / As toads sing all night. / They sing to the females, / they sing for copulation. // That moves the sun and the other stars" (30).

This quoting of the last line of Dante's Comedy, far from blasphemy, is a way of celebrating the union to which everything in nature tends, to make of love a physical energy: electrons and positrons which are always born in pairs, fusion and not fission, "irreversible love" always present in our protoplasm, and Newton who "saw what united / the apple, the earth and the moon": "the dance of energy". The "continual dance of energy" ultimately is "the music of the spheres", the "melody of the waves of the universe" (30):

All is waves.

Movement and rhythm:

The essential form of matter.

The music of the spheres

and the music of atoms and molecules.

Gamma rays-the gamma rays of the present Conference-are waves, declares the poet in Canto 35 (Like the Waves). "The waves of radio, heat, light of different colors, / ultraviolet rays, X rays, gamma rays, are the same / and are distinguishable only by their wavelength". In 1989, Cardenal could not foresee that 35 years later gravitational waves would actually be detected, originating from a pair of merging black holes. But these "ripples in the curvature of spacetime" had been proposed by Poincaré and predicted by Einstein, and Cardenal was prepared to accept their reality on trust. For him, the different waves form a melody, the "harp of the universe" (30).

In canto 20 Cardenal had described its properties, explaining the nature of the music of the spheres. From Pythagoras and Athanasius ("taking the universe into His hands like a lyre'), to Kepler (who regarded it as a "motet" (Saturn and Jupiter, bass; Mars, tenor; Earth and Venus contralto, and Mercury, baritone), to the American Indians, who "came, from the stars they say", from Vitruvius to Confucius: harmony is at the heart of the cosmos. The mimosa, which opens by day and closes by night, moon and the tides, 
the crabs, which know when the tide is out and scurry back to their burrows: one rhythm governs the planets, the atoms, the sea, the apples which ripen and fall, "and Newton's mind". Yes, this is the music of the spheres, closer to jazz than to classical music"-this is the rhythm, the pulsation of the stars, the song of the Creator and of the electrons, of the Earth, of Cántico cósmico, and of Beethoven's quartets (20): "they say the proton resembles a Bach fugue". The universe is music, symphony, and light: all the elements from which Cardenal makes the poetry of the Cántico and the more recent Versos del Pluriverso, ${ }^{9}$ in a vision of the cosmos which is simultaneously astrophysical, biological, teleological, mystic, and poetic.

In 1918 the Russian poetess Marina Tsvetaeva had already composed a short poem which celebrates the poet not only as maker of lines, but also as a discoverer, a true scientist:

Verses grow, like the stars, like roses,
Like beauty - useless at home.

To crowns and apotheoses

There is only one answer: from where this comes to me?

We sleep, and behold, beyond the stone slabs, The heavenly guest, in four petals.

World, try to understand: the poet - while asleep Discovers the law of the stars and the formula of flowers. ${ }^{10}$

Publisher's Note Springer Nature remains neutral with regard to jurisdictional claims in published maps and institutional affiliations.

\footnotetext{
${ }^{9}$ Ernesto Cardenal, Versos del Pluriverso, Madrid, Trotta, 2005: English translation: Pluriverse. New and Selected Poems, ed. J. Cohen, New York, New Directions, 2009, which includes the translation of El telescopio en la noche oscura, Madrid, Editorial Trotta, $1996^{2}$.

10 Marina Tsvetaeva, Stichotvorenija i poemy v pjati tomach, T. II, Stichotvorenija 1917-1922, New York, Russica Publishers, 1982, p. 231: my translation.
} 